Eur. J. Clin. Chem. Clin. Biochem.

Vol. 31, 1993, pp. 759-763

(C) 1993 Walter de Gruyter \& Co. Berlin · New York

\title{
Studies on the Concentration of Arsenic, Selenium, Copper, Zinc and Iron in the Blood of Blackfoot Disease Patients in Different Clinical Stages
}

\author{
By C. T. Wang ${ }^{1}$, C. W. Huang ${ }^{1}$, S. S. Chou ${ }^{2}$, D. T. Lin $^{3}$, S. R. Liau ${ }^{3}$ and R. T. Wang ${ }^{4}$ \\ ${ }^{1}$ Department of Chemistry, Chung-Yuan Christain University \\ ${ }^{2}$ National Laboratories of Food and Drugs Department of Health Executive Yuan \\ 3 Taiwan Provincal Chi-Yi Hospital \\ ${ }^{4}$ Department of Food Sanitation, Ta-Jan Pharmaceutical College \\ Taiwan, Republic of China
}

(Received December 7, 1992/July 14, 1993)

Summary: Flame atomic absorption spectrophotometric methods were developed for the determination of zinc, copper, arsenic, iron and selenium in blood samples. Data from blackfoot disease patients in five clinical stages were compared with those from healthy controls. Copper concentrations were the same for all clinical stages. Arsenic increased in the initial three stages but decreased thereafter, although arsenic was previously considered to be the major causative agent of the disease. The decrease of arsenic in the later stages was attributed to the antagonistic effect of selenium, and the decrease of iron during the progress of the disease is thought to be due to the antagonistic effect of arsenic in the initial stages and the loose of haemoglobin in the later stages.

\section{Introduction}

An endemic peripheral vascular disease called blackfoot disease is suffered by a large number of inhabitants on the southwest coast of Taiwan $(1-6)$. The disease has an insidious onset with numbness or coldness as the initial symptom. It progresses with the development of localized ulceration and subsequent gangrenous changes, giving the characteristic black coloration of dry gangrene. Most patients are permanently maimed as a result of spontaneous or artificial amputation of a portion of the affected extremity (7).

Blackfoot disease is thought to be related to the presence in artesian drinking water of high concentrations of arsenic, silicate, copper, nickel and certain fluorescent compounds, with arsenic as the primary suspect $(8-18)$.

Patients with advanced clinical symptoms should therefore have a high concentration of blood arsenic, but our preliminary results showed a decrease of arsenic in the advanced stages. In order to assess this situation, we determined arsenic, iron, selenium, zinc and copper in blood samples from blackfoot disease patients in different clinical stages. The results indicate a probable antagonistic effect between arsenic and selenium.

\section{Materials and Methods}

Blood samples

One hundred and thirteen blood samples of blackfoot disease patients at five clinical stages according to the criteria set by Drs. U.C. Huang and D. T. Lin (tab. 1), and 49 blood samples of persons with no known history of exposure to arsenic were used. As shown in table 2, there was an even distribution of age and sex between the two groups. Samples were frozen below $-20^{\circ} \mathrm{C}$ until used.

\section{Chemicals and biological standards}

Suprapur grade reagents of E. Merck and high purity water $(18 \mathrm{M} \Omega$ ) were used. Stock solutions containing $1000 \mathrm{mg} / \mathrm{l}$ or $\mathrm{mg} / \mathrm{kg}$ of iron, zinc, copper, selenium and arsenic and working 
Tab. 1. The different stages of blackfoot disease as classified in Chi-Yi hospital, Taiwan

\begin{tabular}{ll}
\hline Stage & Symptom \\
\hline Zero stage & $\begin{array}{l}\text { Assumed to be present in residents of endemic } \\
\text { area without evidence of disease. }\end{array}$ \\
First stage & $\begin{array}{l}\text { Coldness, numbness and pain. } \\
\text { Second stage }\end{array}$ \\
$\begin{array}{l}\text { Evidence of slight ulceration and slight gan- } \\
\text { grenous changes. }\end{array}$ \\
Third stage & $\begin{array}{l}\text { Evidence of definite ulceration and definite } \\
\text { gangrenous changes. }\end{array}$ \\
Fourth stage & $\begin{array}{l}\text { Evidence of gangrenous changes of the af- } \\
\text { fected extremity. Spontaneous or artifical am- } \\
\text { putation of foot. }\end{array}$ \\
\hline
\end{tabular}

Tab. 2. The distribution of specimens

\begin{tabular}{lllllll}
\hline & & \multicolumn{5}{c}{ Different stages of blackfoot disease } \\
\cline { 3 - 7 } & $\begin{array}{l}\text { Con- } \\
\text { trols }\end{array}$ & $\begin{array}{l}\text { Zero } \\
\text { stage }\end{array}$ & $\begin{array}{l}\text { 1st } \\
\text { stage }\end{array}$ & $\begin{array}{l}\text { 2nd } \\
\text { stage }\end{array}$ & $\begin{array}{l}\text { 3rd } \\
\text { stage }\end{array}$ & $\begin{array}{l}\text { 4th } \\
\text { stage }\end{array}$ \\
\hline Male & 26 & 14 & 20 & 13 & 9 & 21 \\
Female & 23 & 5 & 14 & 5 & 2 & 10 \\
\hline
\end{tabular}

Note: The ages of the patients and healthy control persons were about $65 \pm 10$ years. standard solutions were prepared from Merck Titrisol standards by diluting with the high purity water. Containers made of quartz, Teflon, or polypropylene were used throughout. They were immersed in $8 \mathrm{~mol} / 1 \mathrm{HNO}_{3}$ overnight and washed with several changes of distilled water. Biological standards were NIES human hair No. 5, and NBS serum 1598.

\section{Analytical methods}

Atomic absorption spectrophotometer model Z-8000 and its accessory Hydride Formation System HFS-2 from Hitachi, Japan were used for determining trace metals. Prolab Maxdigester 350 (France) was used for sample digestion.

To $10 \mathrm{ml}$ of a whole blood in a digestion flask were added 20 ml of conc. $\mathrm{HNO}_{3}$. The power output of the digester was maintained at $15 \%$ for $15 \mathrm{~min}$ and at $25 \%$ for $10 \mathrm{~min}$. After adding $7 \mathrm{ml}$ each of conc. $\mathrm{H}_{2} \mathrm{SO}_{4}$ and $\mathrm{HClO}_{4}$, the digestion was continued at $30 \%$ power for $10 \mathrm{~min}$ and at $40 \%$ for $35 \mathrm{~min}$ Finally $10 \mathrm{ml}$ of water was added and the power kept at $40 \%$ until a colourless solution was obtained (taking about $8 \mathrm{~min}$ ). The digest was diluted to $50 \mathrm{ml}$ with the high purity water. Aliquots were taken for the ordinary (iron, zinc and copper) and the hydride (arsenic and selenium) modes of atomic absorption spectrophotometer.

\section{Results and Discussion \\ Data accuracy and analyte recovery}

To check the data quality, human serum and hair standards were analysed. As shown in table $3 \mathrm{a}$, the best accuracy, expressed as the \% coefficient of var-

Tab. 3a. Recoveries for the analysis of NBS serum by HFAA and FAA methods $(n=6)$

\begin{tabular}{lllll}
\hline NBS 1598 Serum & FAA** & FAA & FAA & HFAA* \\
& Fe (mg/l) & Cu (mg/l) & Zn (mg/l) & $\begin{array}{l}\text { Se (mg/l) } \\
\text { Analysed }\end{array}$ \\
CV (\%) & $214 \pm 8$ & $0.71 \pm 0.06$ & $0.86 \pm 0.04$ & $0.03 \pm 0.004$ \\
Certified values & $225 \pm 9$ & 8.4 & 4.6 & 11.1 \\
CV (\%) & 4.0 & $0.72 \pm 0.06$ & $0.89 \pm 0.06$ & $0.042 \pm 0.004$ \\
Recovery (\%) & 95 & 8.3 & 6.7 & 9.5 \\
\hline
\end{tabular}

* HFAA: Hydride flame atomic absorption.

** FAA: Flame atomic absorption.

Tab. 3b. Recoveries of the analysis of NIES human hair by HFAA and FAA methods $(n=6)$

\begin{tabular}{|c|c|c|c|c|}
\hline $\begin{array}{l}\text { NIES No. } 5 \\
\text { Human hair*** }\end{array}$ & $\begin{array}{l}\mathrm{FAA} * * \\
\mathrm{Fe}(\mathrm{mg} / \mathrm{kg})\end{array}$ & $\begin{array}{l}\text { FAA } \\
\mathrm{Cu}(\mathrm{mg} / \mathrm{kg})\end{array}$ & $\begin{array}{l}\mathrm{FAA}^{*} \\
\mathrm{Zn}(\mathrm{mg} / \mathrm{kg})\end{array}$ & $\begin{array}{l}\text { HFAA } \\
\mathrm{Se}(\mathrm{mg} / \mathrm{kg})\end{array}$ \\
\hline $\begin{array}{l}\text { Analysed } \\
\text { CV (\%) }\end{array}$ & $\begin{array}{l}2.55 \pm 0.15 \\
6.0\end{array}$ & $\begin{array}{c}15.5 \\
4.5\end{array}$ & $\begin{array}{r}165 \pm 9.0 \\
5.4\end{array}$ & $\begin{array}{l}1.15 \pm 0.25 \\
21.7\end{array}$ \\
\hline $\begin{array}{l}\text { Certified value } \\
\text { CV }(\%)\end{array}$ & $\begin{array}{l}2.55 \pm 0.10 \\
3.9\end{array}$ & $\begin{array}{c}16.3 \pm 1.2 \\
7.3\end{array}$ & $\begin{array}{c}169 \pm 10 \\
5.9\end{array}$ & $1^{1.4^{* * * * *}}$ \\
\hline Recovery (\%) & 100 & 95 & 97 & 83 \\
\hline
\end{tabular}


iation (CV\%) and recovery of analytes from the serum standard, were less than $8.4 \%$ and $98 \%$ for copper, less than $4.6 \%$ and $96 \%$ for zinc, and less than $3.7 \%$ and $95 \%$ for iron, respectively. Selenium, however, had a larger CV\% of 11.1 and a poor recovery of $84 \%$, owing to its volatility. The results in table $3 \mathrm{~b}$ indicated that the best accuracy (CV\%) and recovery of analyses of the human hair standard were less than $6.0 \%$ and $100 \%$ for iron, less than $5.4 \%$ and $97 \%$ for zinc, and less than $4.5 \%$ and $95 \%$ for copper, respectively. Again, selenium had a high CV (21.7\%) and a poor recovery $(83 \%)$. The recoveries of arsenic added to whole blood of normal persons and blackfoot disease patients in the first clinical stage are compared in table 4. Patient samples showed a higher CV $(14.1 \%)$ and a higher recovery $(86.5 \%)$ than samples from controls ( $13.5 \%$ and $84.7 \%$, respectively).

\section{Recovery and standard curves}

Standard and recovery curves of iron, zinc, copper, selenium and arsenic were obtained by analysing normal blood samples. To $1 \mathrm{ml}$ of the sample were added the following:

$0.4,1,2,4$, and $10 \mu \mathrm{g}$ of iron;

$0.2,0.4,1$ and $2 \mu \mathrm{g}$ of zinc and copper;

$2,4,10$ and $20 \mathrm{ng}$ of selenium;

$2,4,10$ and $20 \mathrm{ng}$ of arsenic.

The results are shown in figures 1 and 2. Good linear relationships were obtained for these concentration ranges. Good recoveries of 97,95 and $91 \%$ were obtained for iron, zinc and copper, respectively. Poorer recoveries of 81 and $87 \%$ were obtained for arsenic and selenium, respectively, owing to their volatility.

Tab. 4. Recoveries of arsenic added to whole blood of normal persons and blackfoot disease patients in the first stage of the disease $(n=6)$

\begin{tabular}{llllll}
\hline Whole blood from & $\begin{array}{l}\text { No. } \\
\text { Specimens }\end{array}$ & $\begin{array}{l}\text { As added } \\
(\mu \mathrm{g} / \mathrm{l})\end{array}$ & $\begin{array}{l}\text { As recovered } \\
(\mu \mathrm{g} / \mathrm{l})\end{array}$ & $\begin{array}{l}\text { CV } \\
(\%)\end{array}$ & $\begin{array}{l}\text { Recovery } \\
(\%)\end{array}$ \\
\hline Normal persons & 12 & 40 & $33.9 \pm 4.6$ & 13.5 & 84.7 \\
Blackfoot disease patients & 2 & 40 & $34.6 \pm 4.9$ & 14.1 & 86.5 \\
\hline
\end{tabular}

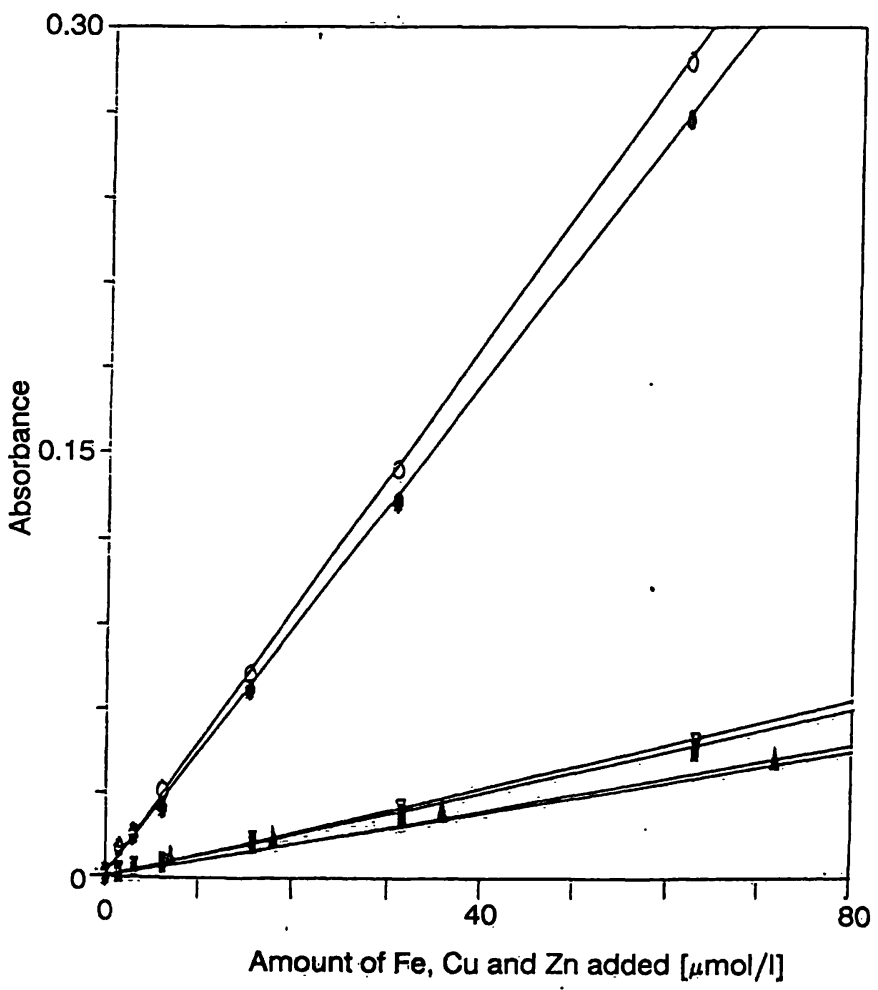

Fig. 1. Assay curves for iron, copper and zinc.
$\triangle \mathrm{Fe}$ in purified water
$\square \mathrm{Cu}$ in purified water
$\circ \mathrm{Zn}$ in purified water
$\triangle \mathrm{Fe}$ in normal person blood
- $\mathrm{Cu}$ in normal person blood
- $\mathrm{Zn}$ in normal person blood

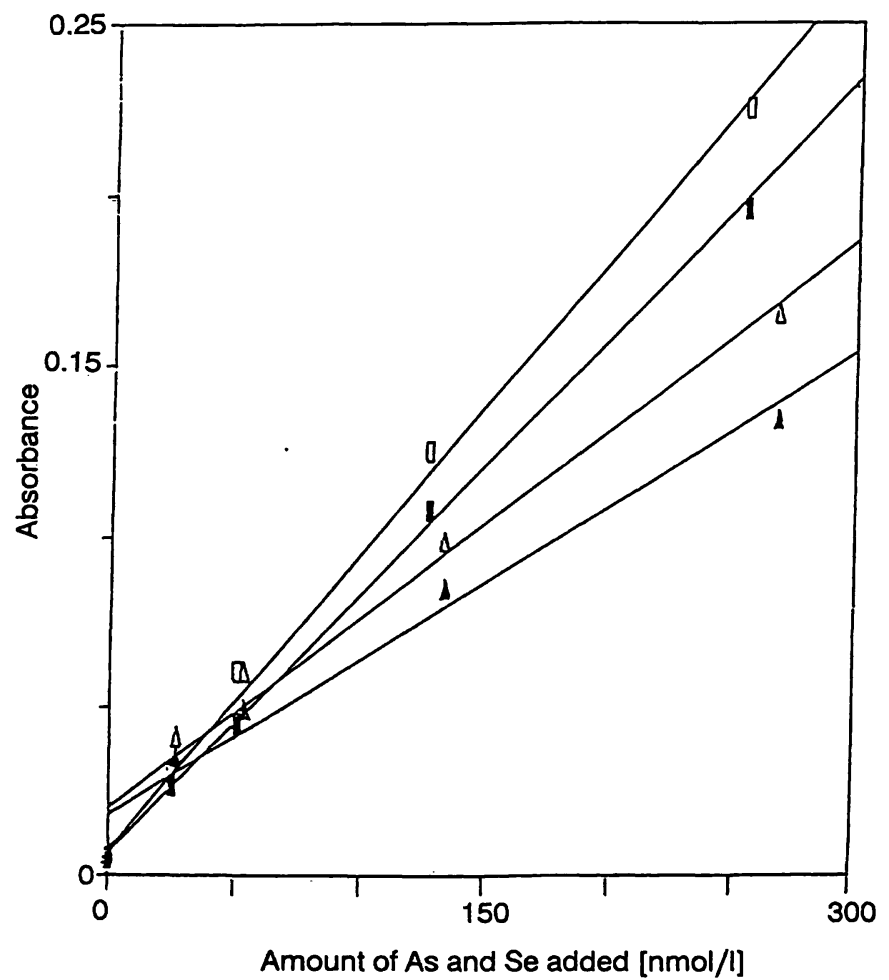

Fig. 2. Standard curves for the assay of arsenic and selenium $\Delta$ As in purified water $\Delta$ As in normal person blood $\square$ Se in purified water $a$ Se in normal person blood 
Tab. 5. Comparisons of blood arsenic, selenium, copper, zinc and iron concentrations of blackfoot disease patients and normal persons

\begin{tabular}{|c|c|c|c|}
\hline & $\begin{array}{l}\text { Normal persons } \\
n=49\end{array}$ & $\begin{array}{l}\text { Patients } \\
\mathrm{n}=113\end{array}$ & $\begin{array}{l}\text { Deviation between normal } \\
\text { person and blackfoot } \\
\text { disease patients } \\
(\%)\end{array}$ \\
\hline $\begin{array}{l}\text { Arsenic (nmol/l) } \\
\text { CV (\%) }\end{array}$ & $\begin{array}{l}89.4 \pm 45.3 \\
50\end{array}$ & $\begin{array}{c}133.4 \\
54\end{array} \pm 72.0$ & +49 \\
\hline $\begin{array}{l}\text { Selenium }(\mu \mathrm{mol} / \mathrm{l}) \\
\text { CV }(\%)\end{array}$ & $\underset{31}{0.79} \pm 0.28$ & $\underset{51}{0.59} \pm 0.30$ & -25 \\
\hline $\begin{array}{l}\text { Copper }(\mu \mathrm{mol} / \mathrm{l}) \\
\text { CV }(\%)\end{array}$ & $9.44 \pm 4.09$ & $\underset{39}{9.11 \pm 3.99}$ & +5 \\
\hline $\begin{array}{l}\operatorname{Zinc}(\mu \mathrm{mol} / \mathrm{l}) \\
\mathrm{CV}(\%)\end{array}$ & $\begin{array}{l}64.3 \pm 21.4 \\
33\end{array}$ & $\begin{array}{l}62.5 \pm 19.5 \\
31\end{array}$ & -2.8 \\
\hline $\begin{array}{l}\text { Iron }(\mu \mathrm{mol} / \mathrm{l}) \\
\text { CV }(\%)\end{array}$ & $\begin{array}{l}9.88 \pm 1.66 \\
16\end{array}$ & $\begin{array}{l}11.5 \pm 3.24 \\
28\end{array}$ & +17 \\
\hline
\end{tabular}

\section{Analyses of blood samples}

Table 5 shows the analytical results of blood samples obtained from the normal and diseased persons without discrimination of clinical stages. It shows that the blood zinc and copper concentrations of patients do not differ from those of normal individuals; they fall within the $5 \%$ deviation (zinc, $64.3 \pm 21.4$ and 62.5 $\pm 19.5 \mu \mathrm{mol} / \mathrm{l}$; copper, $9.44 \pm 4.09$ and $9.11 \pm 3.99$ $\mu \mathrm{mol} / \mathrm{l})$, but arsenic, selenium and iron showed significant differences, with deviations of 49,25 and $17 \%$, respectively (arsenic, $89.4 \pm 45.3$ and 133.4 $\pm 72.0 \mathrm{nmol} / \mathrm{l}$; selenium, $0.79 \pm 0.28$ and $0.59 \pm$ $0.30 \mu \mathrm{mol} / \mathrm{l}$; iron, $9.88 \pm 1.66$ and $11.5 \pm 3.24$ $\mu \mathrm{mol} / \mathrm{l})$. Patient blood samples contained lower selenium concentrations, but higher arsenic and iron concentrations than those of controls. Blood arsenic concentrations of patients in different clinical stages and living in higher endemic areas were compared with those living in lower endemic areas (tab. 6).

Tab. 6. Comparisons of blood arsenic concentrations of blackfoot disease patients from higher and lower endemic areas

\begin{tabular}{llll}
\hline & $\begin{array}{l}\text { Higher } \\
\text { endemic } \\
\text { area } \\
\text { patients }\end{array}$ & $\begin{array}{l}\text { Lower } \\
\text { endemic } \\
\text { area } \\
\text { patients }\end{array}$ & $\begin{array}{l}\text { Deviation be- } \\
\text { tween the higher } \\
\text { and lower en- } \\
\text { demic patients } \\
(\%)\end{array}$ \\
\hline $\begin{array}{l}\text { Arsenic }(\mu \mathrm{g} / \mathrm{l}) \\
\mathrm{CV}(\%)\end{array}$ & $\begin{array}{l}10.5 \pm 5.6 \\
53\end{array}$ & $\begin{array}{l}7.7 \pm 4.3 \\
55\end{array}$ & 26 \\
\hline
\end{tabular}

Samples from patients in higher endemic areas had a significantly higher arsenic value of $10.5 \pm 5.6 \mu \mathrm{g} / \mathrm{l}$ compared with $7.7 \pm 4.3 \mu \mathrm{g} / \mathrm{l}$ in the lower endemic areas, with a deviation of $26 \%$. A positive correlation therefore exists between the blood arsenic concentration and the onset of blackfoot disease.

\section{Antagonism of arsenic by selenium}

Figure 3 shows the analytical results of blood specimens obtained from patients in different clinical stages. It shows that the deviation of blood copper, zinc and iron for either diseased or normal persons were always within $\pm 5 \%$. But arsenic and selenium had a larger deviation of more than $\pm 10 \%$. The copper concentrations for either patients or normal persons have an average value of $9.67 \pm 0.94 \mu \mathrm{mol} / \mathrm{l}$.

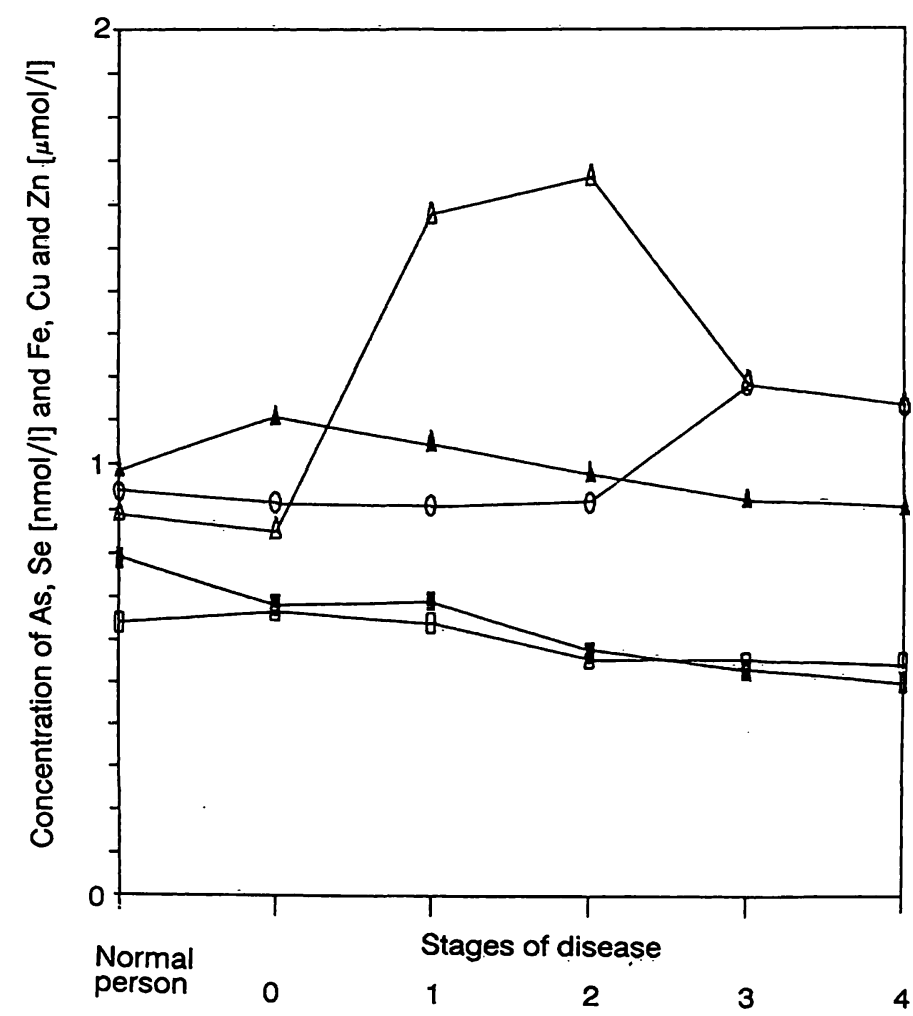

Fig. 3. Blood arsenic, selenium, iron, copper and zinc concentrations in different stages of blackfoot disease. Each value has been divided by the.denominator shown, e.g. the values for As have been divided by 100 .
$\Delta(\mathrm{As} / 100)$
○ $(\mathrm{Cu} / 10)$
- $(\mathrm{Se} / 1000)$
ㅁ $(\mathrm{Zn} / 100)$
$\Delta(\mathrm{Fe} / 10)$

Eur. J. Clin. Chem. Clin. Biochem. / Vol. 31, 1993 / No. 11 
Therefore blood copper seems to have little or no effect on blood arsenic.

Selenium seems to have a relatively large antagonistic effect on blood arsenic; as the clinical stages progressed from zero to stage 2 , the blood arsenic increased significantly from 0.08 to $0.16 \mu \mathrm{mol} / 1$ and selenium from 0.71 to $0.56 \mu \mathrm{mol} / 1$. At the third and fourth stages, the level of selenium is maintained at about $0.50 \mu \mathrm{mol} / \mathrm{l}$, exerting a continual antagonistic effect which causes the blood arsenic to decrease to $0.11 \mu \mathrm{mol} / 1$. This would explain some reports that blackfoot disease patients have lower blood arsenic values, whereas most reports emphasize arsenic as a major causative agent of the disease based on the results of drinking water analyses. This antagonistic effect is not only of academic interest and worthy of further study, but also important in the clinical treatment of blackfoot disease patients.

The blood iron contents of patients decreased as the clinical stages progressed from zero to stage 4 , with values changing from 10.9 to $9.04 \mathrm{mmol} / \mathrm{l}$. Two reasons may be offered for the decrease: 1. the antagonistic effect of arsenic toward iron, and 2. the loss of haemoglobin. The iron status of the patients is also worthy of further study from both the academic and clinical points of view.

\section{References}

1. Tseng, W. P. (1973) The natural history of blackfoot disease. J. Formosan Med. Assoc. 72, 11-24.

2. Yeh, S. \& How, S. W. (1963) A pathological study in blackfoot disease in Taiwan. Reports, institute of pathology, National Taiwan unjversity. No. 14, 25-73.

3. Tseng, W. P., Chen, W. Y. \& Sung, J. L. (1961) A clinical study of blackfoot disease in Taiwan, an endemic pheripheral vascular disease. Memoirs of college of medicine of the National Taiwan Univ., Vol. 7, 1-17.

4. Chen, K. P. \& Wu, H. Y. (1962) Epidemiologic studies of blackfoot disease in Taiwan: A study of sources of drinking water in relation to the disease. J. Formosan Med. Assoc. 61, 611-618.

5. Tseng, W. P. (1968) Prevalence of skin cancer in an endemic area of chronic arsenicism in Taiwan. J. Nat. Cancer Inst. $40,453-463$.

6. Chen, K. P. (1962) Epidemiologic studies on blackfoot diesease in Taiwan. 3. Physiochemical characteristics of drinking water in endemic blackfoot disease area. Memoirs College of Medicine National Taiwan Univ. 8, 115-129.

7. Lo, M: C., Hsen, Y. C. \& Lin, B. K. (1977) The Second Report on Investigation of Arsenic Content in Underground Water in Taiwan Province Taipei. Provincial Institute of Environmental Sanitation.

8. Lu, F. J. (1978) Study on fluorescent compounds in drinking water of endemic areas for blackfoot disease and reinvestigation of causes of blackfoot disease. National Science Council Monthly 6, 388-402.

9. Lu, F. J. \& Liu, T. M. (1986) Fluorescent compounds in drinking water of blackfoot disease endemic areas animal experimental model. J. Formosan Med. Assoc. 85, 352358.

10. Lu, F. J. (1988) Fluorescent humic substançes and endemic disease in south-western Taiwan. J. Chinese Biochemical Society $17,57-47$.

11. Wu, H. Y. \& Chen, K. P. (1961) Epidemiologic studies on blackfoot disease. 1. Prevalence and incidence of disease by age, sex, year, population, and geographic distribution. Memoirs College of Medicine National Taiwan Univ. 7, 33.
12. Tseng, W. P. (1970) Prognosis of blackfoot disease: A ten year follow-up study. J. Formosan Med. Assoc. 69, 1-21.

13. Prasad, A. S. (1979) Clinical, biochemical and pharmacological role of zinc. Ann. Rev. Pharmacol. Toxicol. 20, $393-426$.

14. Hsieh, H. S. \& Ganther, H. E. (1977) The biotransformation of selenite to selenide and excretable methylated metabolites. Biochim. Biophys. Acta 497, 205-217.

15. Lin, S. M., Chiang, C. H. \& Yang, M. H. (1985) Arsenic concentration in the urine and blood of patients with blackfoot disease and bowen's disease. Biol. Trace Element Res. $8,11-19$.

16. Keshan Disease Research Group (1979) Higher risked of the keshan disease with the lower concentration of food selenium. Clin. Med. J. 92, 471-482.

17. Magos, L. \& Webb, M. (1980) The interactions of selenium with cadmium and mercury. CRC. Crit. Rev. Toxicol. 8, $1-41$.

18. Chen, $X$. (1980) Studies the selenium concentration in blood of the keshan disease patients. Biol. Trace Element Res. 2, $91-107$.

19. Laker, M. (1964) On determining trace element levels in man: The uses of blood and hair. Lancet 2, 260-262.

20. Liebscher, K. \& Smith, H. (1968) Essential and nonessential trace elements. Determining whether an element is essential or nonessential in human tissue. Arch. Environ. Health 17, $881-890$.

21. Heydorn, K. (1970) Environmental variation of arsenic levels in human blood determined by neutron activation analysis. Clin. Chim. Acta 28, 349-357.

22. Lin, S. M., Chiang, C. H. \& Yang, M. H. (1985) Determination of arsenic in urine and whole blood by hydric atomic absorption spectrophotometry. Kaohsiung J. Med. Sci. 1, 105-112.

23. Lin, S. M. (1986) Diagnostic usefulness of trace arsenic in human urine, whole blood, hair and fingernails. Kaohsiung J. Med. Sci. 2, 100-113.

24. Maxdigester-350 handbook (1990) Prolabo, France.

\author{
C. T. Wang \\ 1F, No. 1, Aly. 61 \\ Lin. 114, Sec. 7 \\ Chung Shan N. Road \\ Taipei \\ Taiwan \\ R.O.C.
}


